\title{
Genetic relationships among accessions of African indigenous melons (Cucumis melo L. ssp. agrestis) using AFLP markers
}

\author{
Kouamé Kevin Koffi ${ }^{a}{ }^{*}$, Bi Irié Vroh ${ }^{b}$, Jean-Pierre Baudoin ${ }^{c}$, \\ Bi Irié Arsène Zoro ${ }^{a}$ \\ ${ }^{a}$ Université Nangui Abrogoua, UFR des Sciences de la Nature, 02 BP 801 Abidjan 02, Cote d'Ivoire \\ b Senior Expert (Science \& Technology Policy), African Observatory of Science Technology and Innovation (AOSTI), Malabo, Equatorial \\ Guinea \\ c Unité de Phytotechnie Tropicale et d'Horticulture, Université de Liège - Gembloux Agro-Bio Tech, Passage des Déportés, 2., B-5030 \\ Gembloux, Belgium
}

\section{A R T I C L E I N F O}

\section{Article history:}

Received 19 April 2014

Accepted 7 June 2014

Available online

\section{Keywords:}

AFLP

Cucumis melo L. ssp. agrestis

Genetic diversity

Relationships

\begin{abstract}
A B S T R A C T
Cucumis melo ssp. agrestis is among the most important cucurbit consumed in Côte d'Ivoire. Two varieties were identified and used in different areas. One is eaten as soup thickener and the second is used as vegetable. In spite of the socio cultural importance of this species, knowledge of its genetic diversity and differentiation is very poor. Little information is available on the variety itself or relationships between the both varieties. Amplified fragment length polymorphism (AFLP) markers were employed to determine the genetic relationships between these varieties in Côte d'Ivoire. Five AFLP primer combinations were used for this study. A total of 75 loci were observed in the 24 accessions with $82.16 \%$ of polymorphic loci ranging between $13.3 \%$ and $100 \%$. The averages of total gene diversity $\left(\mathrm{H}_{\mathrm{T}}\right)$ and within accessions genetic diversity $(\mathrm{Hs})$ were 0.313 and 0.273 respectively. The inter accessions genetic diversity $\left(D_{S T}\right)$ and the coefficient of gene differentiation among cultivars ( $\mathrm{F}_{\mathrm{ST}}$ ) were 0.040 and 0.129 respectively. Cluster analysis using Unweighted Pair-Group Method using Néi's genetic distance highlighted two main clusters indicating clearly separation between vegetable and thickener cultivars of Cucumis melo L. ssp. agrestis consumed in Côte d'Ivoire. These data are useful for best management of genetics resources of Cucumis melo L. ssp. agrestis.
\end{abstract}

() 2014 Elsevier Ltd. All rights reserved.

\section{Introduction}

Melon family is an economically important crop that includes wild types and numerous varieties, consumed worldwide either as desert fruits, vegetable or sauce ingredients, depending on the type of fruit. Varieties vary widely in fruit size, morphology and taste, as well as vegetative traits and climatic adaptation (Pitrat et al., 1999). Cucumis melo L. is reported to be the most variable species in the genus Cucumis (Akashi et al., 2002). The diversity in cultivation areas, uses, and morphology certainly reflect the growing number of research programs conduced namely on evolution and genetics (Silberstein et al., 1999) of C. melo. These studies are mainly aimed at assessing the intra-genus diversity and the identification of the closest

\footnotetext{
* Corresponding author. Tel.: +225 098726 98, +225 02287699 .

E-mail address: koffikevin@yahoo.fr (K.K. Koffi).
} 
relatives of $C$. melo. Such investigations are of practical interest for germplasm management and for plant breeders. Ongoing investigations on evolution, systematics and genetics of melon are based either on morphological traits, isozymes- or PCRbased techniques (Djè et al., 2006; Staub et al., 1997, 2000). Relevant results have been obtained from these studies, allowing authors to refine melon species classification. Thus, it has been established that the genus Cucumis is subdivided into two subgenera designated Cucumis $(n=7)$ and Melo $(n=12)$, with 4 and 5 species, respectively. Africa, where wild and free-living species occur has been identified as the most likely centre of origin for the genus Cucumis. It has been suggested that the probable sites of domestication of melon and cucumber is Middle East and Southern Asia (Pitrat et al., 1999). To date, melon intra-species classification is still unclear. Further investigations are needed to elucidate their evolutionary genetics and phylogeny. Varieties of melon cultivated in temperate zones have been relatively well studied using morphological and molecular analysis. So far, the classification within the African indigenous melon has not been investigated using similar approaches. To our knowledge only a few studies have been conducted on intraspecific genetic variability and phylogeny of the African indigenous melon using morphological traits (Djè et al., 2006), isozymes (Staub et al., 1997) and RAPD (Staub et al., 2000).

The African Cucumis species (wild or domesticated) represent reservoirs of potential useful genes for the improvement of current cultivars of cucumber and melon. The edible types, widely adopted in many tropical regions of the world are important for food security (Badifu and Ogunsua, 1991; de Mello et al., 2001; Loukou et al., 2007). In Côte d'Ivoire, a 6-years (2000-2006) country level prospecting resulted in the collection of 101 accessions of $C$. melo. (taxon agrestis) composed of two andromonoecious types classified by peasants as varieties. Preliminary studies have established morphological differentiation between both varieties. This work is carried out to investigate the genetic diversity and relationship within and among the two presumed varieties of $C$. melo. (taxon agrestis) using DNA variations.

\section{Material and methods}

\subsection{Plant material}

Twenty four accessions of $C$. melo ssp. agrestis were selected from indigenous cucurbits germplasm collection maintained at Nangui Abrogoua University (Abidjan, Côte d'Ivoire). The selected accessions identified by alpha-numeric codes (Table 1), were representative of the main agro-ecological zones of Côte d'Ivoire in which this species is regularly produced (Zoro Bi et al., 2006). Accessions were selected from the collection of 101 introductions to represent the two cultivars of $C$. melo var. agrestis produced in Côte d'Ivoire and to maximize the range of morphological diversity and geographical origin.

Two andromonoecious variety of $C$. melo ssp. agrestis, with dark green leaves, yellow flowers, and small oval fruits (3-10 cm length) occur in Côte d'Ivoire. The most common type is cultivated. The seeds of this variety are toasted, ground, and eaten as soup thickener. The flesh of fruits is light green, lacks aroma, and has bitter taste. The second variety, less widely cultivated, is often found along the roads, on rubbish sites or on unbuilt plots in villages and cities. Its mature fruits are orange, possess aroma and are exclusively used as vegetable. The fruits are cut into slices and added to soup.

Table 1

Accession codes, cultivar, collection site, and sample sizes for Cucumis melo ssp agrestis used for AFLP analysis.

\begin{tabular}{|c|c|c|c|}
\hline Codes & Cultivars & Collection site & Geographic coordinate \\
\hline NI057 & Thickener & Assiè-Assasso & $6^{\circ} 39^{\prime} \mathrm{N}-4^{\circ} 11^{\prime} \mathrm{W}$ \\
\hline NI064 & Thickener & Assiè-Koumassi & $6^{\circ} 43^{\prime} \mathrm{N}-4^{\circ} 21^{\prime} \mathrm{W}$ \\
\hline NI104 & Thickener & Assiè-Assasso & $6^{\circ} 39^{\prime} \mathrm{N}-4^{\circ} 11^{\prime} \mathrm{W}$ \\
\hline NI136 & Thickener & Assiè-Assasso & $6^{\circ} 39^{\prime} \mathrm{N}-4^{\circ} 11^{\prime} \mathrm{W}$ \\
\hline NI139 & Thickener & Assiè-Assasso & $6^{\circ} 39^{\prime} \mathrm{N}-4^{\circ} 11^{\prime} \mathrm{W}$ \\
\hline NI142 & Thickener & Assiè-Koumassi & $6^{\circ} 43^{\prime} \mathrm{N}-4^{\circ} 21^{\prime} \mathrm{W}$ \\
\hline NI150 & Thickener & Assiè-Koumassi & $6^{\circ} 43^{\prime} \mathrm{N}-4^{\circ} 21^{\prime} \mathrm{W}$ \\
\hline NI158 & Thickener & Assiè-Assasso & $6^{\circ} 39^{\prime} \mathrm{N}-4^{\circ} 11^{\prime} \mathrm{W}$ \\
\hline NI159 & Thickener & Assiè-Assasso & $6^{\circ} 39^{\prime} \mathrm{N}-4^{\circ} 11^{\prime} \mathrm{W}$ \\
\hline NI168 & Thickener & Assiè-Assasso & $6^{\circ} 39^{\prime} \mathrm{N}-4^{\circ} 11^{\prime} \mathrm{W}$ \\
\hline NI169 & Thickener & Assiè-Assasso & $6^{\circ} 39^{\prime} \mathrm{N}-4^{\circ} 11^{\prime} \mathrm{W}$ \\
\hline NI186 & Vegetable & Riviera Lauriers 9 & $5^{\circ} 21^{\prime} \mathrm{N}-3^{\circ} 56^{\prime} \mathrm{W}$ \\
\hline NI197 & Thickener & Korhogo & $9^{\circ} 23^{\prime} \mathrm{N}-5^{\circ} 33^{\prime} \mathrm{W}$ \\
\hline NI253 & Thickener & Lobouakouzin & $5^{\circ} 45^{\prime} \mathrm{N}-3^{\circ} 46^{\prime} \mathrm{W}$ \\
\hline NI378 & Thickener & Korhogo & $9^{\circ} 23^{\prime} \mathrm{N}-5^{\circ} 33^{\prime} \mathrm{W}$ \\
\hline NI380 & Thickener & Korhogo & $9^{\circ} 23^{\prime} \mathrm{N}-5^{\circ} 33^{\prime} \mathrm{W}$ \\
\hline NI400 & Thickener & Boflêkro & $6^{\circ} 38^{\prime} \mathrm{N}-4^{\circ} 42^{\prime} \mathrm{W}$ \\
\hline NI405 & Thickener & Assié Assasso & $6^{\circ} 39^{\prime} \mathrm{N}-4^{\circ} 11^{\prime} \mathrm{W}$ \\
\hline NI413 & Vegetable & Yakasse Me & $5^{\circ} 49^{\prime} \mathrm{N}-3^{\circ} 56^{\prime} \mathrm{W}$ \\
\hline NI415 & Vegetable & Abié & $5^{\circ} 49^{\prime} \mathrm{N}-3^{\circ} 56^{\prime} \mathrm{W}$ \\
\hline NI416 & Vegetable & Akin & $5^{\circ} 42^{\prime} \mathrm{N}-3^{\circ} 32^{\prime} \mathrm{W}$ \\
\hline NI417 & Vegetable & Awakoua & $5^{\circ} 42^{\prime} \mathrm{N}-3^{\circ} 52^{\prime} \mathrm{W}$ \\
\hline NI418 & Vegetable & Awakoua & $5^{\circ} 42^{\prime} \mathrm{N}-3^{\circ} 52^{\prime} \mathrm{W}$ \\
\hline NI424 & Vegetable & Awakoua & $5^{\circ} 42^{\prime} \mathrm{N}-3^{\circ} 52^{\prime} \mathrm{W}$ \\
\hline
\end{tabular}


Table 2

Mean $( \pm$ SE) of intra- and inter-accession gene diversity indices for 24 indigenous oilseed melon (Cucumis melo L. ssp. agrestis) accessions from Côte d'Ivoire.

\begin{tabular}{lll}
\hline Genetic diversity indices & Collection $(n=24)$ & Thickener $(n=14)$ \\
\hline Total number of loci & 75 & 75 \\
Number of polymorphic loci & $70.42 \pm 2.04$ & $60.29 \pm 27.35$ \\
Percent of polymorphic loci $(5 \%)$ & $93.90 \pm 2.72$ & $80.39 \pm 36.47$ \\
Total gene diversity $\left(\mathrm{H}_{\mathrm{T}}\right)$ & 0.313 & 0.279 \\
Within accessions gene diversity (Hs) & $0.273 \pm 0.010$ & $0.252 \pm 0.017$ \\
Among accessions gene diversity ( $\left.\mathrm{D}_{\mathrm{ST}}\right)$ & $0.040 \pm 0.007$ & $0.027 \pm 0.017$ \\
Among accessions gene differentiation $\left(\mathrm{F}_{\mathrm{ST}}\right)$ & $0.129 \pm 0.167$ & 0.310 \\
\hline
\end{tabular}

\subsection{DNA extraction and AFLP analysis}

Ten to thirteen seeds of each accession were sown in a greenhouse (IITA, Ibadan, Nigeria) and after 4-6 days, total genomic DNA was extracted from 0.15 to $0.2 \mathrm{~g}$ of young leaves collected from 4 seedling of each accession following the CTAB extraction procedure according to Doyle \& Doyle method (Doyle and Doyle, 1988) with minor modification. The DNA final concentration was determined by $2 \%$ agarose-gel electrophoresis. AFLP was performed with partial modifications of Keygene method (Vos et al., 1995). In brief, $0.5 \mu \mathrm{g}$ of genomic DNA was restricted with 5 U EcoRI and 1 U PstI (New England Biolabs) for $2 \mathrm{~h}$ at $37^{\circ} \mathrm{C}$ and then ligated to EcoRI and PstI adapters using $1 \mathrm{U}$ T4 DNA ligase (New England Biolabs). Restriction and ligation were carried out in a single reaction containing $1 \times$ T4 ligase buffer with ATP; $0.05 \mathrm{M} \mathrm{NaCl}, 0.5 \mu \mathrm{g}$ bovine serum albumin (BSA), and $1 \mu \mathrm{L}$ each of EcoRI and PstI adapter pairs. The diluted restricted-ligated DNA was amplified employing EcoRI and PstI preselective primers using AFLP core mix supplied with the kit; $0.05 \times$ diluted amplified product was used for selective amplification. Five AFLP primer combinations were employed for the generation of markers: EcoRI-AAC + PstI-CAC; EcoRIACC + PstI-CAA; EcoRI-ACT + PstI-CTA; EcoRI-AGG + PstI-CAG and EcoRI-AGC + PstI-CAC. Amplified fragments were detected by silver staining. The resulting gels were scored manually.

\subsection{Data collection and analysis}

The number of monomorphic and polymorphic AFLP fragments was determined for each primer pair. Presence or absence of each fragment was scored as $1=$ present, 0 = absent. Bands of similar size and intensity were assumed to be homologous, since paternity and mating system studies have highlighted the Mendelian inheritance of AFLP markers. Genetic variation within each accession was estimated, using AFLPSURv (Vekemans et al., 2002), by the percentage of polymorphic loci (PPL) at the $5 \%$ level based on the approach of Lynch and Milligan (1994) and the expected heterozygosity (Hj), using the Bayesian method with nonuniform prior distribution of allele frequencies. Estimates of the partitioning of total genetic variation were calculated by $\mathrm{F}_{\mathrm{ST}}$ using aflpsurv and by analysis of molecular variance (AMOVA) following the methods of Excoffier et al. (1992) and using GenAlex version 5 (Peakall and Smouse, 2001). A phylogenetic tree was constructed by the neighbour-joining method (Saitou and Nei, 1987) using the neighbour program in Phylip version 3.63 (Felsenstein, 1993). One thousand bootstraps, performed over loci, of Nei's unbiased genetic distance $(D)$ from AFLP polymorphism were constructed using the Bayesian method with nonuniform prior distribution of allele frequencies, and an assumption of Hardy-Weinberg equilibrium, in aflpsurv (Vekemans et al., 2002), to infer confidence levels for tree branches.

\section{Results}

Primer pairs used in this study generated an average 69 bands per individual, ranging from 12 to 96 , and $83.65 \%$ polymorphic bands were observed in the total of 253 bands. A total of 75 loci were observed in the 24 accessions. The proportion of polymorphic loci (PPL) evaluated at $95 \%$ criterion varied from $13.3 \%$ to $100 \%$ with a mean of $82.16 \%$. At the cultivar level, the proportion of polymorphic loci varied from $13.3 \%$ to $100 \%$ for thickener cultivars and $14.7 \%-100 \%$ for vegetable cultivars with respective mean of $80.39 \%$ and $86.49 \%$. The averages of total gene diversity $\left(\mathrm{H}_{\mathrm{T}}\right)$ and within accessions genetic diversity (Hs) were 0.313 and 0.273 , respectively. These values were 0.279 and 0.252 in thickener cultivars and 0.310 and 0.293 for vegetable cultivars. The inter accessions genetic diversity $\left(\mathrm{D}_{\mathrm{ST}}\right)$ and the coefficient of gene differentiation among cultivars $\left(\mathrm{F}_{\mathrm{ST}}\right)$ were 0.040 and 0.129 , respectively. At the cultivar level, among accessions gene diversity $\left(\mathrm{D}_{\mathrm{ST}}\right)$ and among accessions gene differentiation ( $\mathrm{F}_{\mathrm{ST}}$ ) were 0.027 and 0.097 for thickener cultivar (Table 2). These indices were 0.016 and 0.052 for vegetable cultivar.

The UPGMA phylogenetic tree based on the Nei's genetic distances matrix from AFLP data is shown in Fig. 1. A clear accessions grouping supported by relatively high number of bootstrap was observed. The phenogram subdivided the accessions analysed into two major groups: group I composed of vegetable (V) cultivars and group II composed of thickener (T) cultivars.

\section{Discussion}

Cucumis melo, is one of the members of cucurbit family for which classification is unclear because of the high number of varieties or cultivars described (Pitrat, 2013; Stepansky et al., 1999), stirring controversy between scientist (Achigan and 


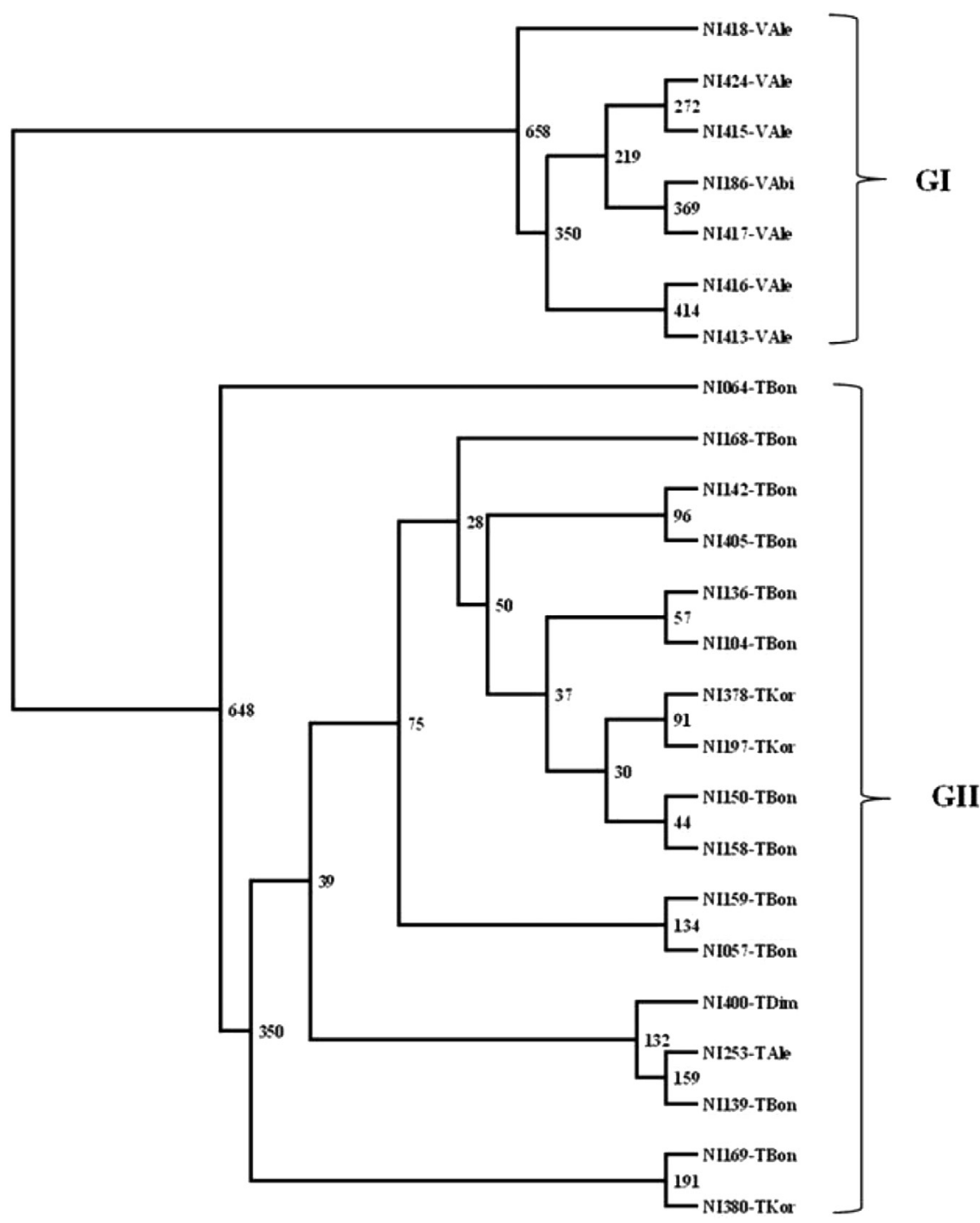

Fig. 1. UPGMA dendrogram for 24 accessions of the indigenous melon, using Nei's genetic distance and based on 1000 bootstraps. "T" and "V" in the accessions' ID indicate thickener and vegetable, respectively. Numbers on each branch are bootstrap values.

Baudoin, 2007). In Côte d'Ivoire two varieties have been described as Cucumis melo var agrestis based of morphological traits (Djè et al., 2006; Zoro Bi et al., 2006). The most common variety is cultivated for its seeds eaten as sauce thickener. This variety is similar to those described by Pitrat (2013) as typical wild melons. The second variety less widely cultivated in the sampled zones, is often found along the roads. Except for the yellow skin colour, they look like the "wild" melons described above. In this study we compared at the molecular level in order to evaluate intraspecific variability and to describe the relationships amongst them. The assessment of genetic diversity is important not only for crop improvement but also for efficient management and conservation of germplasm resources. Ability of AFLP analysis to display genetic relationships among accessions has been widely demonstrated (Stepansky et al., 1999; Talebi et al., 2008; Zhang et al., 2012). Morphological characterization is important to genetic diversity evaluation but it is not enough to appreciate the variability within a species. Elucidating the genetic relationships within the genus Cucumis is of great importance because the closest relatives and natural composition can provide valuable information to genetics resources management.

Genetics analysis carried out revealed a high proportion of polymorphic loci (82.16\%). The high level of polymorphism detected indicates that these AFLP markers provide a useful tool for estimating genetic variation in melon. This result indicated also that Ivoirian accessions of Cucumis melo exhibited great genetic diversity. Our result was similar to those reported by McCreight and Staub (2004) for certain group of melon in India and China Cucumis melo germplasm collections using isozyme variation and agreed, broadly, with intraspecific variability of this species reported by Stepansky et al. (1999). On the other hand, estimates of the genetic structure indicated that $C$. melo maintained a high level of its variability within accessions. The same trend is observed in each variety. This result suggests that to capture variability effort must be 
concentrated on the number of individual per accession. The relatively high level of the within accessions and cultivars genetic diversity component compared to the genetic variation among accessions and cultivars was also in accordance with the mating system coupled with farmers' seed management approaches. The low genetic differentiation between accessions $\left(F_{\mathrm{ST}}=0.129\right)$ was observed. It indicated the important rate of gene exchange between accessions.

A study based on life cycle duration, seed size and seed weight analysis exhibited the morphological distinction established between the two types C. $m$. subsp. agrestis by peasants (Zoro Bi et al., 2006). The UPGMA dendrogram generated from AFLP data was supported by high bootstrap values, thereby implying the high reliability of the pattern found. The dendrogram divided accessions into two highly supported clusters, both of which consisting of the two varieties. This result confirmed morphological distinction and rural communities separation of Ivoirian Cucumis melo (Zoro Bi et al., 2006). The neighbourjoining tree constructed based on AFLP fragments supports the view that cultivars are distinct. It could be indicated that Ivoirian cultivars of Cucumis melo might belong to different botanical groups.

\section{Acknowledgement}

Research financed by the Direction Général de la Cooperation au Développement, Brussels, Belgium and supervised by the Comité Universitaire pour le Developpement, Brussels, Belgium.

\section{References}

Achigan, D.G.E., Baudoin, J.-P., 2007. Cucumis melo L. subsp agrestis (Naudin) Pangalo (Cucurbitaceae): nécessité de clarification sur le statut de la sousespèce. Biotechnol. Agron. Soc. Environ. 11, 283-286.

Akashi, Y., Fukuda, N., Wako, T., Masuda, M., Kato, K., 2002. Genetic variation and phylogenetic relationships in East and South Asian melons, Cucumis melo L. , based on the analysis of five isozymes. Euphytica 125, 385-396.

Badifu, G.I.O., Ogunsua, A.O., 1991. Chemical composition of kernels from some species of Cucurbitaceae grown in Nigeria. Plant Food Hum. Nutr. 41, 35-44. de Mello, M.L.S., Bora, P.S., Narain, N., 2001. Fatty and amino acids composition of melon (Cucumis melo var. saccharinus) seeds. J. Food Comp. Anal. 14, 69-74.

Djè, Y., Kouonon, L.C., Zoro Bi, A.I., Gnamien, G.Y., Baudoin, J.-P., 2006. Étude des caractéristiques botaniques, agronomiques et de la biologie florale du melon africain (Cucumis melo L. var. agrestis Naudin, Cucurbitaceae). Biotechnol. Agron. Soc. Environ. 10, $109-119$.

Doyle, J.J., Doyle, J.L., 1988. Isolation of plant DNA from fresh tissue. Focus 12, 13-15.

Excoffier, L., Smouse, P.E., Quattro, J.M., 1992. Analysis of molecular variance inferred from metric distances among DNA Haplotypes: application to human mitochondrial DNA restriction data. Genetics 131, 479-491.

Felsenstein, J., 1993. Phylogeny Inference Package Version ver.3.5. Department of Genetics, University of Washington, Seattle, USA.

Loukou, A.L., Gnakri, D., Djè, Y., Kippré, A.V., Malice, M., Baudoin, J.-P., Zoro Bi, I.A., 2007. Macronutrient composition of three cucurbit species cultivated for seed consumption in Côte d'Ivoire. Afr. J. Biotechnol. 6, 529-533.

Lynch, M., Milligan, B.G., 1994. Analysis of population genetic structure with RAPD markers. Mol. Ecol. 3, 91-99.

McCreight, J.D., Staub, J.E., 2004. Isozyme variation in Indian and Chinese melon (Cucumis melo L.) germplasm collections. J. Am. Soc. Hort. Sci. $129,811-818$.

Peakall, R., Smouse, P.E., 2001. GENALEX. Genetic Analysis in Exce Population Gene Tic Software for Teaching and Research; Version 61 Australian. National University, Canberra (Australia). www.anu.edu.au/BoZo/GenAlEx/.

Pitrat, M., 2013. Phenotypic diversity in wild and cultivated melons (Cucumis melo). Plant. Biotechnol. 30, $273-278$.

Pitrat, M., Chauvet, M., Foury, C., 1999. Diversity, history, production of cultivated cucurbits. Acta. Hort. 92, $21-28$.

Saitou, N., Nei, M., 1987. The neighbor-joining method: a new method for reconstructing phylogenetic trees. Mol. Biol. Evol. 4, 406-425.

Silberstein, L., Kovalski, I., Huang, R., Anagnostou, K., Kyle Jahn, M.M., Perl-Treves, R., 1999. Molecular variation in melon (Cucumis melo L.) as revealed by RFLP and RAPD markers. Sci. Hort. 79, 101-111.

Staub, J.E., Box, J., Meglic, V., Horejsi, T.F., McCreight, J.D., 1997. Comparison of isozyme and random amplified polymorphic DNA data for determining intraspecific variation in Cucumis. Gen. Res. Crop Evol. 44, 257-269.

Staub, J.E., Danin-Poleg, G., Fazio, Y., Horejsi, T., Reis, N., Katzir, N., 2000. Comparison analysis of cultivated melon groups (Cucumis melo L.) using random amplified polymorphic DNA and simple sequence repeat markers. Euphytica 115, 225-241.

Stepansky, A., Kovalski, I., Perl-Treves, R., 1999. Intraspecific classification of melons (Cucumis melo L.) in view of their phenotypic and molecular variation. Plant. Syst. Evol. 217, 313-333.

Talebi, R., Naji, A.M., Fayaz, F., 2008. Geographical patterns of genetic diversity in cultivated chickpea (Cicer arietinum L.) characterized by amplified fragment length polymorphism. Plant Soil. Environ. 54, 447-452.

Vekemans, X., Beauwens, T., Lemaire, M., Roldan-Ruiz, I., 2002. Data from amplified fragment length polymorphism (AFLP) markers show indication of size homoplasy and of a relationship between degree of homoplasy and fragment size. Mol. Ecol. 11, $139-151$.

Zhang, C., Pratap, A.S., Natarajan, S., Pugalendhi, L., Kikuchi, S., Sassa, H., Senthil, N., Koba, T., 2012. Evaluation of morphological and molecular diversity among South Asian germplasms of Cucumis sativus and Cucumis melo. Int. Sch. Res. Netw. 12, 11. Article ID 134134.

Zoro Bi, I.A., Koffi, K.K., Djè, Y., Malice, M., Baudoin, J.-P., 2006. Indigenous Cucurbits of Côte d'Ivoire: a review of their genetic resources. Sci. Nat. 3, 1-9. 